\title{
Effect of a rosmarinic acid supplemented hemodialysis fluid on inflammation of human vascular endothelial cells
}

\author{
W-J. Wang ${ }^{1,2}, \mathrm{M}-\mathrm{H}$. Cheng ${ }^{3}, \mathrm{~J}-\mathrm{H} . \mathrm{Lin}^{2}$ and C-S. Weng ${ }^{1}$ \\ ${ }^{1}$ Department of Biomedical Engineering, Chung Yuan Christian University, Chungli, Taiwan \\ ${ }^{2}$ Division of Nephrology, Department of Internal Medicine, Taoyuan General Hospital, \\ Ministry of Health and Welfare, Taoyuan, Taiwan \\ ${ }^{3}$ Department of Rehabilitation, TaoYuan General Hospital, Ministry of Health and Welfare, Taoyuan, Taiwan
}

\begin{abstract}
Chronic systemic inflammation and repetitive damage of vascular endothelia by incompatible dialysis system are probable causes of cardiovascular disease in patients on dialysis. The present study aimed to assess in vitro biocompatibility and anti-inflammatory effect of hemodialysis fluid supplemented with rosmarinic acid (RA) using human umbilical vein endothelial cells (HUVEC). HUVECs $\left(5 \times 10^{6}\right.$ cells $\left./ \mathrm{mL}\right)$ were pre-exposed to $1 \mu \mathrm{g} / \mathrm{mL}$ of lipopolysaccharides (LPS) and incubated with RA-supplemented hemodialysis fluid (HDF). Cytotoxicity was assessed qualitatively by morphologic assessment and quantitatively by MTT assay. Expressions of proinflammatory mediators were assessed using quantitative real-time PCR and production of NO was quantified. Phosphorylation of AKT and nuclear localization of nuclear factor kappa B (NF-kB) were examined using western blotting. Exposure of HUVECs to RA-supplemented HDF had no influence on morphology and viability. Inhibition of proinflammatory mediator production in HUVECs by RA supplementation to HDF was significant in a dose-dependent manner. Exposure to RA-supplemented HDF resulted in a decrease in nitric oxide synthase expression and reduction of NO production in LPS-stimulated HUVECs. RA supplementation of HDF suppressed Akt activation in LPS-stimulated HUVECs. In

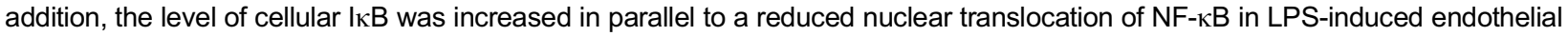
cells. Our results suggest that RA-supplemented HDF is biocompatible and significantly suppressed inflammation induced in endothelial cells. In this respect, the use of HDF supplemented with RA could alleviate inflammation and improve long-term treatment of patients with renal failure on dialysis. Further clinical studies are required to confirm the effects.
\end{abstract}

Key words: Rosmarinic acid; Hemodialysis fluid; Anti-inflammation; Endothelial cells; LPS

\section{Introduction}

Chronic kidney disease (CKD) is characterized by a slow decline in renal function and progresses to end-stage renal disease (ESRD). Kidney transplantation has been recognized as the optimal treatment for ESRD patients with prolonged survival and improved quality of life (1). However, given the increased incidence of ESRD and shortage of available organs, most patients with ESRD rely on some form of dialysis to compensate for renal insufficiency. Mortality and morbidity rates of ESRD patients on dialysis remain high due to cardiovascular diseases such as atherosclerosis (2-5). Factors contributing to vascular abnormality include hypertension, hyperglycemia, uremia, dyslipidemia and proteinuria $(6,7)$. Recently, chronic inflammation has been considered to play a critical role in the pathogenesis of vascular disease in ESRD patients maintained on dialysis (8). It is known that levels of C-reactive protein and proinflammatory cytokines are elevated and associated with high cardiovascular mortality in ESRD patients (9). Inflammation in dialysis patients is plausibly attributed to insufficient cytokine clearance, accumulated reactive oxygen species and oxidative damage due to renal failure (10). In addition, bioincompatibility of the dialysis system has been reported to promote chronic inflammation in patients on dialysis. Although the mechanism underlying inflammation in CKD remains unclear, modulation of pro-inflammation represents a promising strategy to manage the poor outcome of CKD.

Rosmarinic acid ( $\alpha$-o-caffeoyl-3, 4-dihydroxyphenyl lactic acid; RA) is a phenolic compound commonly found in Labiatae herbs such as rosemary, lemon balm, mint, perilla and sweet basil. Several studies have reported that RA possesses anti-inflammatory properties such as reducing 
histamine release of mast cells, blocking complement activation, and inhibiting cyclooxygenase activity (11-14). In vivo studies have shown that $\mathrm{RA}$ inhibits several complement-dependent inflammatory processes, including cobra venom factor-induced paw edema and ovalbumin/ antiovalbumin-mediated passive cutaneous anaphylaxis $(15,16)$. In addition, RA has been shown to exert an antioxidative effect by reducing liver damage induced by D-galactosamine and lipopolysaccharides in mice (17).

In the present study, we evaluated the biocompatibility of hemodialysis fluid (HDF) supplemented with RA. The effects of RA-supplemented HDF were assessed on cell viability and production of pro-inflammatory cytokines in transcriptional and translational levels. In addition, the mechanism underlying the anti-inflammatory effect of RA-supplemented HDF was elucidated.

\section{Material and Methods}

\section{Chemicals and reagents}

Aprotinin, leupeptin, $2^{\prime}, 7^{\prime}$-dichlorofluorescin diacetate, lipopolysaccharides (LPS), 3-(4,5-dimethylthiazol-2-yl)2,5-diphenyl-tetrazolium bromide (MTT), Nonidet P-40, phenylmethylsulfonyl fluoride (PMSF), RA, sodium fluoride, sodium chloride, sodium phosphate, Tris- $\mathrm{HCl}$, Triton $X-100$, and Tween-20 were purchased from Sigma-Aldrich (USA). Bicarbonate-based buffer hemodialysis concentrate No. 110 was obtained from Taiwan Biotech Co. (Taiwan). Dulbecco's-modified Eagle's medium F12 (DMEM-F12), RPMI-1640 medium and fetal bovine serum (FBS) were obtained from Gibco (USA).

\section{Cell culture and treatment}

Human umbilical vein endothelial cells (HUVECs) were isolated from normal human umbilical cords, digested with $0.05 \%$ trypsin containing $0.02 \%$ EDTA, and eluted with DMEM-F12. Cells were grown in DMEM-F12 supplemented with $10 \%$ FBS, $100 \mathrm{U} / \mathrm{mL}$ penicillin, and $100 \mathrm{U} / \mathrm{mL}$ streptomycin. Cells were maintained in a $37^{\circ} \mathrm{C}$ humidified incubator with $5 \% \mathrm{CO}_{2}$ to reach $80 \%$ confluency. Passages 2-6 were used for experiments. RA-supplemented HDF was prepared by dissolving RA in HDF. HUVECs were pretreated with $1 \%$ FBS DMEM-F12 for $16 \mathrm{~h}$, and then treated with $1 \mu \mathrm{g} / \mathrm{mL}$ LPS in the presence or absence of RA $(5-50 \mu \mathrm{M})$ in HDF for $30 \mathrm{~min}$ (immunoblot assay), $4 \mathrm{~h}$ (PCR and quantitative realtime PCR analysis), or $24 \mathrm{~h}$ (cell viability assay). Thereafter, cells were washed twice with phosphate-buffered saline (PBS), pH 7.4, for further assay.

\section{Cell viability}

Cell viability was determined by mitochondrialdependent reduction of MTT to formazan. Briefly, $10 \mu \mathrm{L}$ of MTT solution ( $5 \mathrm{mg} / \mathrm{mL}$ in DMEM) was added to the cell supernatant and incubated for $4 \mathrm{~h}$ at $37^{\circ} \mathrm{C}$. After removal of medium, 2-propanol was added to lyse cells and to solubilize formazan. The absorbance of formazan was measured using a microplate reader (Benchmark, Bio-Rad Laboratories, USA) at $570 \mathrm{~nm}$. The absorbance of formazan generated by untreated cells was taken as $100 \%$.

\section{RNA extraction, RT-PCR and quantitative real-time PCR (qPCR)}

Total RNA was isolated using the RNeasy kit (Qiagen, USA) according to the manufacturer's instructions. The purified RNA was used as a template to generate firststrand cDNA synthesis using RevertAid ${ }^{\mathrm{TM}}$ First Strand cDNA Synthesis Kit (Fermentas, Life Sciences, Germany). The primer sequences used for RT-PCR and qPCR are listed in Table 1. RT-PCR experiments were performed in triplicates for each sample. qPCR was performed using the ABI PRISM 7700 sequence detection system (Applied Biosystems, USA). For mRNA quantitation, FastStart Universal SYBR Green Master (Roche Applied Science, Germany) was used for Taqman PCR. The threshold cycle numbers were calculated using the $\triangle \Delta C T$ relative value method and normalized to GAPDH. qPCR experiments were performed in duplicates for each sample. The correct size of the PCR products was confirmed by agarose gel electrophoresis.

\section{Nitric oxide assay}

Nitric oxide (NO) levels in cell culture supernatant fractions were determined using the Griess reaction. In brief, Raw264.7 cells were treated with 1,5 , or $15 \mu \mathrm{g} / \mathrm{mL}$ PFE for $1 \mathrm{~h}$, followed by incubation with $1 \mu \mathrm{g} / \mathrm{mL}$ LPS for $24 \mathrm{~h}$. Nitrite in the culture supernatants was mixed with the same volume of Griess reagent ( $1 \%$ sulfanilamide and $0.1 \% \mathrm{~N}$-[1-naphthyl]-ethylenediamine dihydrochloride in $5 \%$ phosphoric acid). Absorbance at $540 \mathrm{~nm}$ was measured, and the nitrite concentration was determined using sodium nitrite $\left(\mathrm{NaNO}_{2}\right)$ as a standard.

Table 1. List of primer sequences.

\begin{tabular}{|c|c|}
\hline Target gene & \\
\hline \multicolumn{2}{|l|}{ IL-1 $\beta$} \\
\hline Forward & 5'-AACCTGCTGGTGTGTGACGTT-3' \\
\hline Reverse & 5'-CAGCACGAGGCTTTTTTTGTT-3' \\
\hline \multicolumn{2}{|r|}{ ( } \\
\hline Forward & 5'-ATGAACTCСTTCTCCACAAGCGC-3 \\
\hline Reverse & 5'-CAAGAGCCCTCAGGCTGGACTG-3' \\
\hline \multicolumn{2}{|l|}{ iNOS } \\
\hline Forward & 5'-GCGGAGCGATGGGAAGCATG-3' \\
\hline Reverse & 5'-CCCGAGCTCCTGGAACCAC-3' \\
\hline \multicolumn{2}{|l|}{ TNF- $\alpha$} \\
\hline Forward & 5'-CACGCTCTTCTGTCTACTGA-3' \\
\hline Reverse & 5'-GGACTCCGTGATGTCTAAGT-3' \\
\hline \multicolumn{2}{|l|}{ GAPDH } \\
\hline Forward & 5'-ACCACAGTCCATGCCATCAC-3' \\
\hline Reverse & 5'-TCCACCACССTGTTGCTTGA-3' \\
\hline
\end{tabular}




\section{Subcellular fractionation}

Cells were washed with PBS and incubated with a lysis buffer (10 mM HEPES, pH 7.6, containing $15 \mathrm{mM} \mathrm{KCl}$, $2 \mathrm{mM} \mathrm{MgCl}_{2}, 0.1 \mathrm{mM}$ EDTA, $1 \mathrm{mM}$ dithiothreitol, 0.05\% v/v Igepal CA-630 and $1 \mathrm{mM}$ PMSF, $1 \mathrm{mM}$ sodium orthovanadate, $50 \mathrm{mM}$ sodium fluoride, $10 \mu \mathrm{g} / \mathrm{mL}$ leupeptin, and $10 \mu \mathrm{g} / \mathrm{mL}$ aprotinin) for $10 \mathrm{~min}$. Cell lysates were centrifuged at $2500 \mathrm{~g}$ for $10 \mathrm{~min}$ at $4^{\circ} \mathrm{C}$. The supernatant containing the cytosol (cytosolic fraction) was further centrifuged at $20,000 \mathrm{~g}$ for $15 \mathrm{~min}$ at $4^{\circ} \mathrm{C}$. The pellets containing nuclei were washed with PBS, resuspended in nuclear buffer (25 mM HEPES, pH 7.6, 0.1\% v/v Igepal CA-630, $1 \mathrm{M} \mathrm{KCl,}$ $0.1 \mathrm{mM}$ EDTA, $1 \mathrm{mM}$ PMSF, $1 \mathrm{mM}$ sodium orthovanadate, $2 \mathrm{mM}$ sodium fluoride, $10 \mu \mathrm{g} / \mathrm{mL}$ leupeptin, and $10 \mu \mathrm{g} / \mathrm{mL}$ aprotinin), and centrifuged at $10,000 \mathrm{~g}$ for $15 \mathrm{~min}$ at $4^{\circ} \mathrm{C}$. The resulting supernatant, namely nuclear fraction, was collected.

\section{Immunoblot assay}

Cells $\left(5 \times 10^{5}\right.$ cells $\left./ \mathrm{mL}\right)$ were harvested, washed twice with ice-cold PBS, and lysed in a lysis buffer (50 mM Tris$\mathrm{HCl}, \mathrm{pH} 7.5,150 \mathrm{mM} \mathrm{NaCl}, 1 \%$ v/v Igepal CA-630, $1 \mathrm{mM}$ PMSF, $1 \mathrm{mM}$ sodium fluoride, and $10 \mu \mathrm{g} / \mathrm{mL}$ aprotinin and leupeptin). The cell lysates were centrifuged at $14,000 \mathrm{~g}$ for $10 \mathrm{~min}$ at $4^{\circ} \mathrm{C}$ to remove debris. The supernatants were collected and crude protein concentrations were determined using $\mathrm{BCA}^{\mathrm{TM}}$ protein assay kit (Pierce, USA). Crude proteins (30 $\mu \mathrm{g}$ per lane) were electrophoresed on $12.5 \%$ SDS-polyacrylamide gel, and transferred onto a nitrocellulose membrane (Millipore, USA). The blotted membrane was blocked with $5 \% \mathrm{w} / \mathrm{v}$ skim milk in PBS, and then incubated for $2 \mathrm{~h}$ with $1 / 1000$ dilution of the specific antibodies against phosphorylated AKT (pAKT), AKT,

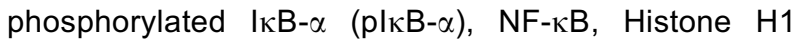
(Cell Signaling Technologies, USA) or glyceraldehyde 3-phosphate dehydrogenase (GAPDH; Abcam, UK). Bound antibodies were detected using 1/2000 dilution of peroxidase-conjugated secondary antibodies (Abcam) and ECL chemiluminescence reagent (Millipore) as the substrate system.

\section{Statistical analysis}

Data are reported as means \pm SD of three independent experiments. Statistical comparisons were made by oneway analysis of variance (ANOVA), followed by Duncan's multiple-comparison test. Student's $t$-test was employed to determine the significance of the difference between two groups. Differences were considered significant when $P$ values were $<0.05$.

\section{Results}

\section{Cytotoxicity of RA-supplemented HDF}

As shown in Figure 1A, HUVECs were incubated with HDF supplemented with a serial concentration of RA ( 0 , 10 , and $50 \mu \mathrm{M})$ for $24 \mathrm{~h}$, and the morphology of treated HUVECs was slightly affected. Additionally, cytotoxicity was not significant compared to controls (Figure 1B). These results revealed that HDF supplemented with RA ( $\leqslant 50 \mu \mathrm{M}$ ) had no significant influence on morphology and cell viability of HUVECs.

\section{RA-supplemented HDF inhibited proinflammatory mediator production}

Endotoxin is a robust stimulator to activate vascular endothelium, consequently leading to systemic inflammatory responses (18). Therefore, effects of RA-supplemented HDF on LPS-induced mRNA expression of inflammatory mediators in HUVECs were investigated. As shown in Figure $2 A$, mRNA expressions of IL-1 $\beta, I L-6$ and TNF- $\alpha$ in HUVECs were significantly increased in response to the presence of LPS, and reduced in the presence of RA-supplemented HDF in a dose-dependent manner. Quantitative analysis using q-PCR revealed that HDF supplemented with $30 \mu \mathrm{M}$ RA suppressed average mRNA expression of IL-1 $\beta$, IL- 6 and TNF- $\alpha$ to $25.6,24.4$, and $30.4 \%$ of LPS-alone, respectively $(P<0.05$; Figure $2 B-D)$. These results showed that RA-supplemented HDF was capable of significantly reducing LPS-induced mRNA expression of IL-1 $\beta$, IL-6, and TNF- $\alpha$ in HUVECs.

\section{RA-supplemented HDF inhibited mRNA expression of iNOS and the consequent NO production}

NO, synthesized by inducible nitric oxide synthase (iNOS), is an important inflammatory mediator secreted by LPS-stimulated endothelial cells (19). Therefore, effects of RA-supplemented HDF on mRNA expression of iNOS and NO production by HUVECs were investigated. As shown in Figure 3A, mRNA expression level of iNOS in HUVECs was significantly elevated by LPS, and diminished by HDF supplemented with serial concentrations of RA $(10,20$, and $30 \mu \mathrm{M})$ in a dose-dependent manner. Moreover, quantitative analysis using q-PCR revealed that HDF supplemented with $30 \mu \mathrm{M}$ RA suppressed mRNA expression of iNOS to $20.8 \%$ of TNF- $\alpha$ alone $(\mathrm{P}<0.05$; Figure $3 \mathrm{~B})$. NO production of LPSstimulated HUVECs was also determined. As shown in Figure 3C, exposure of HUVECs to LPS resulted in a significant increase in NO production, and the level of NO induced by LPS was suppressed by HDF supplemented with serial concentrations of $\mathrm{RA}(10,20$, and $30 \mu \mathrm{M})$ in a dosedependent manner. Quantitative analysis using sodium nitrite as standard revealed that HDF supplemented with $30 \mu \mathrm{M}$ RA suppressed NO production to $20.8 \%$ of LPS alone $(P<0.05$; Figure $3 C)$. These findings revealed that RAsupplemented HDF significantly inhibited LPS-induced iNOS expression and the consequent NO production by HUVECs.

RA-supplemented HDF suppressed phosphorylation of AKT and $I \kappa B-\alpha$ and nuclear translocation of NF- $\kappa B$ in LPS-stimulated HUVECs

Activation of AKT and the subsequent nuclear translocation of transcription factor NF- $\kappa B$ play important roles in production of proinflammatory cytokines. Therefore, effects 
A
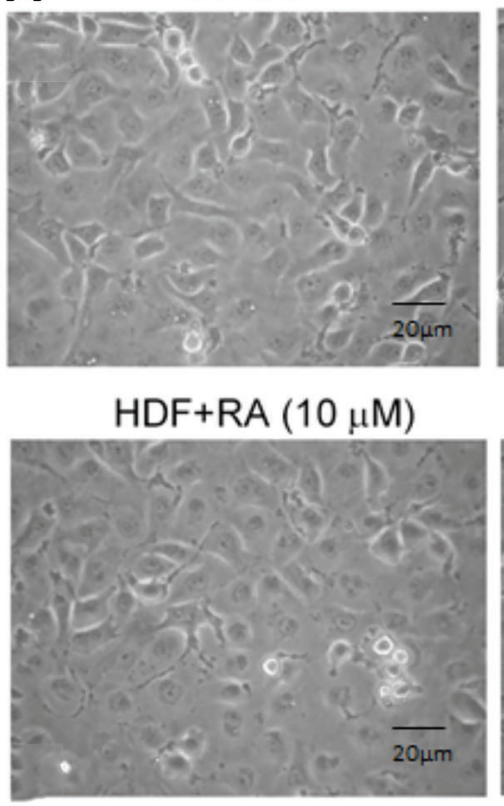

B

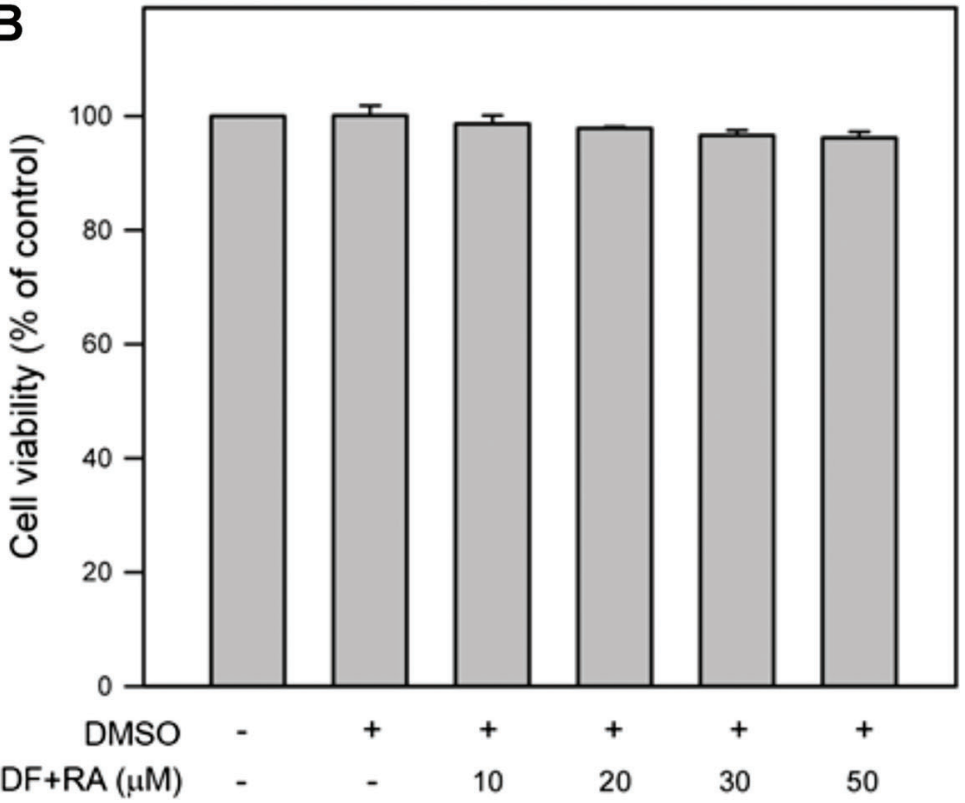

Figure 1. Effects of hemodialysis fluid (HDF) supplemented with rosmarinic acid (RA) on morphology and viability of human umbilical vein endothelial cells. $A$, Cells were treated with HDF or HDF supplemented with $10 \mathrm{mM}$ or $50 \mathrm{mM}$ RA for $24 \mathrm{~h}$, and the cell morphology was monitored by phase-contrast microscopy $(400 \times)$. $B$, Cells were treated with DMSO, HDF or HDF supplemented with serial concentrations of RA for $24 \mathrm{~h}$, and the cell viability was determined by MTT assay. These results revealed that HDF supplemented with RA ( $\leqslant 50 \mu \mathrm{M})$ had no significant influence on morphology and cell viability of HUVECs. of RA-supplemented HDF on phosphorylation of AKT and nuclear translocation of NF- $\mathrm{BB}$ in LPS-stimulated HUVECs were determined. As shown in Figure 4, exposure to LPS led to significantly increased phosphorylation of AKT in HUVECs, and the phosphorylation of AKT induced by LPS was decreased with the presence of HDF supplemented with RA $(10,20$, and $30 \mu \mathrm{M})$ in a dose-dependent manner. In addition, phosphorylation of $\mathrm{I} \kappa \mathrm{B}-\alpha$ and $\mathrm{NF}-\kappa \mathrm{B}$ inhibitor, concomitantly with nuclear translocation of $\mathrm{NF}-\kappa \mathrm{B}$, was increased in LPS-stimulated HUVECs. The increases of

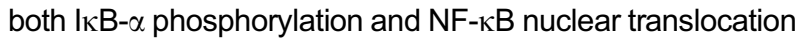

were inhibited by HDF supplemented with RA (10, 20, and $30 \mu \mathrm{M}$ ) in a dose-dependent manner. These findings revealed that HDF supplemented with RA was capable of attenuating LPS-induced AKT activation, $1 \kappa B-\alpha$ phosphorylation and $\mathrm{NF}-\kappa \mathrm{B}$ translocation.

\section{Discussion}

For patients with CKD on hemodialysis, endotoxins come not only from the gut, but also from impure dialysate, which contains endotoxin derived from environmental 
A

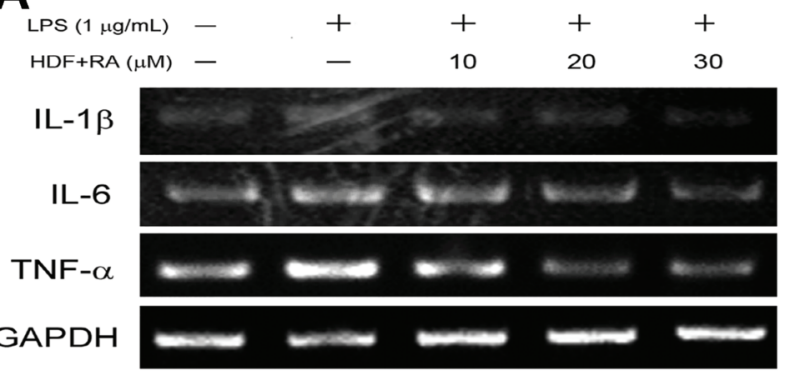

B

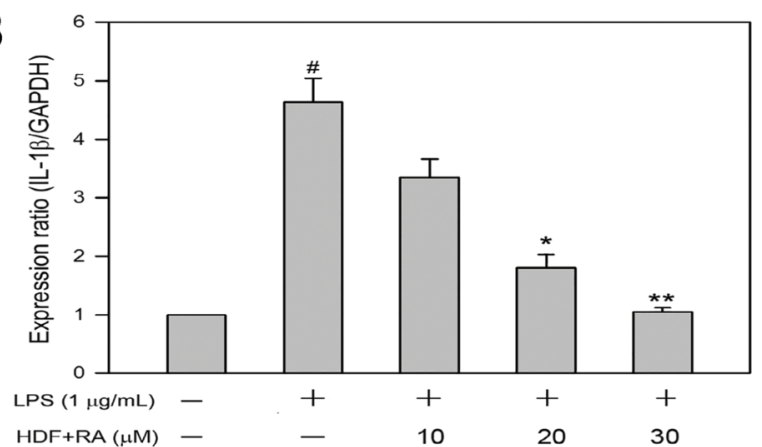

C

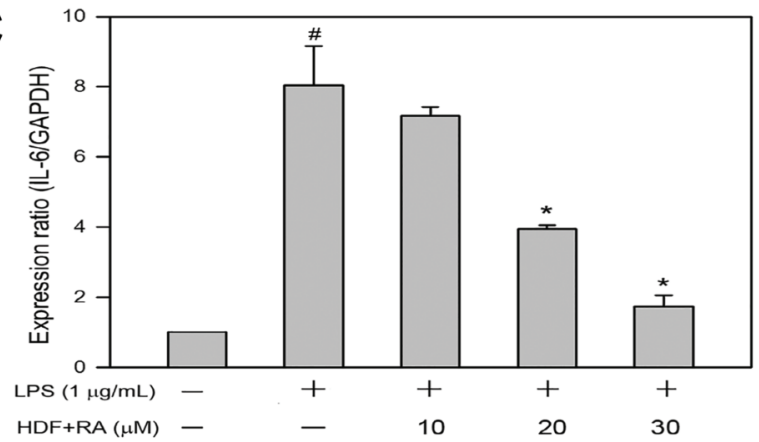

D

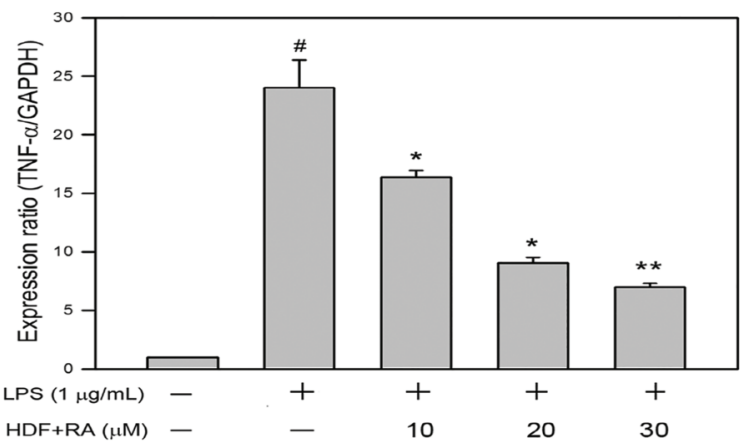

Figure 2. Hemodialysis fluid (HDF) supplemented with rosmarinic acid (RA) inhibited mRNA expression of pro-inflammatory cytokines in LPS-stimulated human umbilical vein endothelial cells. Detection and quantitation of IL-1 $\beta$, IL- 6 and TNF- $\alpha$ were done by A, RT-PCR, and $B-D, q-P C R$. Data are reported as means \pm SD. Three independent experiments were performed for quantitative and statistical analysis. ${ }^{*} \mathrm{P}<0.05$ compared to control; ${ }^{*} \mathrm{P}<0.05$ and ${ }^{* *} \mathrm{P}<0.005$ compared to LPS alone (ANOVA).
A $\begin{array}{llllll}\mathrm{LPS}(1 \mu \mathrm{g} / \mathrm{mL}) & - & + & + & + & + \\ \mathrm{HDF}+\mathrm{RA}(\mu \mathrm{M}) & - & - & 10 & 20 & 30\end{array}$
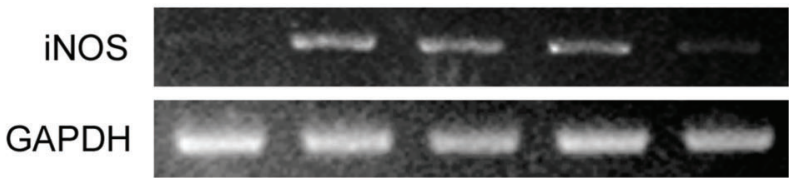

B

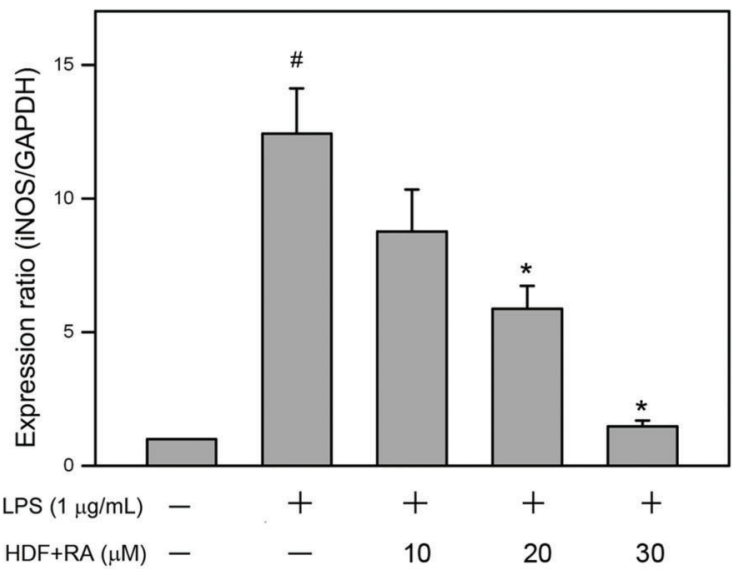

C

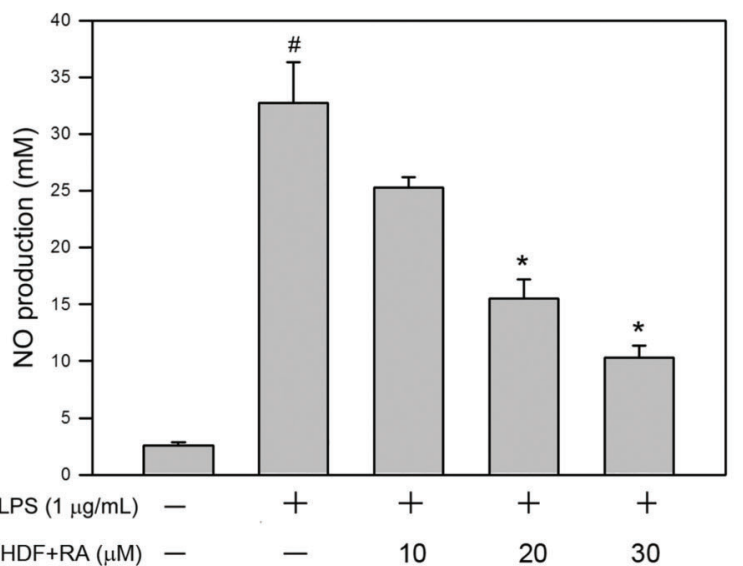

Figure 3. Hemodialysis fluid (HDF) supplemented with rosmarinic acid (RA) suppressed mRNA expression of inducible nitric oxide synthase (iNOS) and nitric oxide (NO) production by lipopolysaccharides (LPS)-stimulated human umbilical vein endothelial cells. Detection and quantitation of iNOS were done by RT-PCR $(A)$, and q-PCR $(B)$. The culture medium after the treatment was collected for $\mathrm{NO}$ assay. The concentration of NO was determined by Griess reagent using $\mathrm{NaNO}_{2}$ as standard (C). Data are reported as means $\pm S D$. Three independent experiments were performed for quantitative and statistical analysis. ${ }^{\#} \mathrm{P}<0.05$ compared to control; ${ }^{*} \mathrm{P}<0.05$ compared to LPS alone (ANOVA).

bacteria. Even a low level of endotoxemia constitutes chronic inflammation, which has been proposed to play a major role in the development of cardiovascular diseases and mortality among patients with renal failure $(20,21)$. 

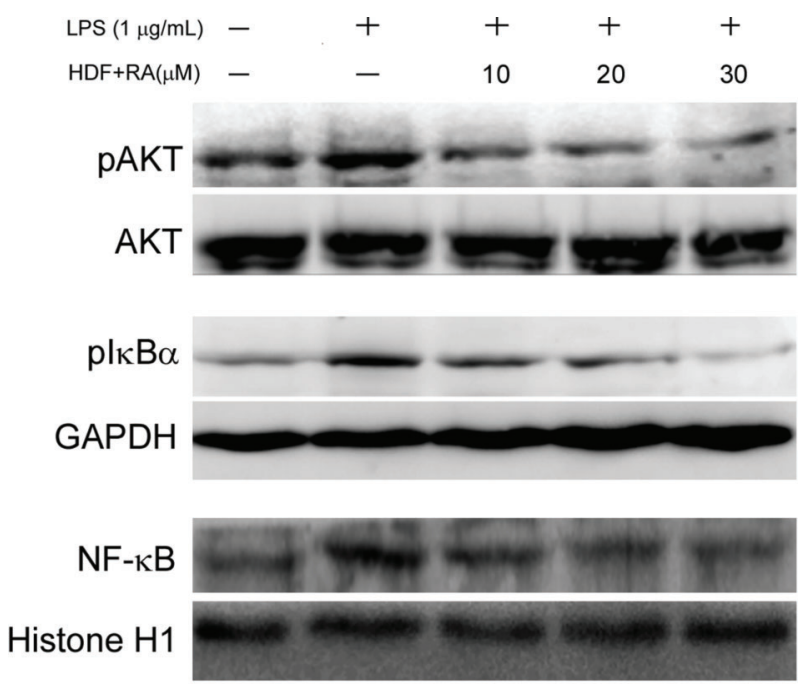

Figure 4. Hemodialysis fluid (HDF) supplemented with rosmarinic acid (RA) increased phosphorylation of cytosolic AKT and I $\mathrm{B} \alpha$ and diminished nuclear NF- $\mathrm{KB}$ in lipopolysaccharides (LPS)stimulated human umbilical vein endothelial cells. Phosphorylation of cytosolic AKT and $I \kappa B-\alpha$, and the level of nuclear NF- $\kappa B$ were determined by immunoblot using specific antibodies and chemiluminescence development. Levels of GAPDH and histone $\mathrm{H} 1$ were used as cytosolic and nuclear control.

A recent study also suggests that vein endothelial cells may play important roles in the pathophysiology of systemic inflammation-associated diseases such as sepsis and septic cardiomyopathy (22). Therefore, diminishing exposure to endotoxin and suppressing endotoxin-induced chronic inflammation are important and urgent for the patients on hemodialysis.

Circulating LPS in blood contributes to vascular inflammation through the activation of endothelial cells and vascular smooth muscular cells (23). Endotoxin concentration in hemolysis patients with systemic inflammation is suggested to be as low as $1 \mathrm{EU} / \mathrm{mL}$. Previous studies have reported that IL-1 $\beta$, IL- 6 and TNF- $\alpha$ are over-expressed in HUVEC exposed to LPS $(22,24,25)$. IL-6 possesses various biological properties in a number of chronic endothelial dysfunctions such as modulation of hematopoiesis, proliferation and differentiation of lymphocytes, and induction of acute-phase reactions (26). In addition, both IL-1 $\beta$ and IL-6 are also known as key mediators in chronic inflammation and are associated with long-term hemodialysis complications such as erythropoietin hyporesponsiveness, cardiovascular morbidities and amyloidosis-related bone disease $(27,28)$. In addition to environmental factors such as LPS, genomic research has highlighted the contribution of nonenvironmental factors to the development of arthrosclerosis in hemodialysis patients $(29,30)$. In the present study, we employed HUVEC as a cell model to explore the effectiveness of RA supplementation in HDF on LPS $(1 \mu \mathrm{g} / \mathrm{mL})$ induced inflammatory responses. Our findings confirmed that IL-1 $\beta$, IL-6, and TNF- $\alpha$ were over-expressed in HUVEC exposure to LPS and demonstrated that HDF supplemented with RA significantly inhibited over-expression of IL-1 $\beta$, IL-6, and TNF- $\alpha$ in LPS-stimulated HUVECs. According to the experimental setting, it is suggested that RA supplement has a potential to alleviate chronic inflammation of endothelial cells induced by endotoxin even up to a concentration of $1 \mu \mathrm{g} / \mathrm{mL}$. However, further studies in vivo and in the clinical setting are required to explore the effectiveness of RAsupplemented HDF on reducing hemodialysis-associated inflammation. Moreover, in vivo studies for toxicological risk assessment of RA are critically necessary.

It is well known that endotoxemia leads to excessive production of the vasodilator NO via iNOS $(31,32)$. The highly elevated NO production further causes downregulation of endothelial NOS (eNOS), leading to an attenuated endothelium-dependent vasodilatory response (33). Consistently, over-expression of iNOS and elevation of NO production were detected in HUVECs treated with LPS. The over-expression of iNOS and elevation of NO production in LPS-treated HUVECs were significantly inhibited by RA-supplemented HDF. However, given the complexity of vasculature, further animal studies are required to confirm the findings obtained using HUVEC cell model and to elucidate the responses of lymphocytes and leukocytes to RA-supplemented HDF in vascular tissues.

Activation of AKT and the subsequent nuclear translocation of transcription factor $\mathrm{NF}-\kappa \mathrm{B}$ play important roles in

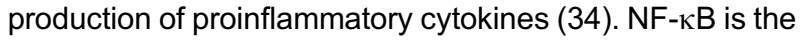
primary transcription factor mainly involved in regulating inflammatory and immune responses to extracellular stimulus. Upon activation, inhibitory protein $1 \kappa B-\alpha$ is rapidly phosphorylated and attributed to nuclear translocation of NF-KB (p65), which binds to related DNA elements and activates its target genes such as IL-1 $\beta$ and IL-6 (35). To investigate the inhibitory mechanism of $\mathrm{IL}-1 \beta$ and IL-6 expression in HUVECs, we examined the effect of RA-supplemented HDF on $I \kappa B-\alpha$ phosphorylation and nuclear NF- $\mathrm{B}$. Our findings showed that the levels of

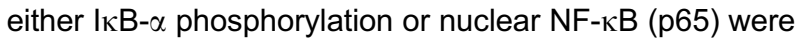
markedly decreased in LPS-induced HUVECs as a result of RA supplementation, suggesting that this is mediated through its influence on $1 \kappa B-\alpha$ phosphorylation, thereby decreasing the nuclear translocation of NF- $\mathrm{NB}$.

In conclusion, we demonstrated that HDF supplemented with RA did not affect morphology or viability of human endothelial cells and exerted inhibitory effects on LPSinduced inflammatory responses, including expression of IL-1 $\beta$, IL-6, TNF- $\alpha$, and iNOS, as well as NO production. These results suggest that RA-supplemented HDF is biocompatible and that RA significantly inhibits upregulation of inflammatory mediators induced by LPS, suggesting that RA is a potential supplement for most patients on dialysis. Further in vivo studies are necessary to examine the usefulness of RA-supplemented HDF in clinical practice. 


\section{References}

1. Horl WH, de Alvaro F, Williams PF. Healthcare systems and end-stage renal disease (ESRD) therapies - an international review: access to ESRD treatments. Nephrol Dial Transplant 1999; 14 (Suppl 6): 10-15, doi: 10.1093/ndt/14.suppl_6.31.

2. Groothoff JW, Lilien MR, van de Kar NC, Wolff ED, Davin JC. Cardiovascular disease as a late complication of endstage renal disease in children. Pediatr Nephrol 2005; 20: 374-379, doi: 10.1007/s00467-004-1624-8.

3. Lambert MC, Vijt D, de Smet R, Lameire N, Bernaert P. Cardiovascular risk factors and their management in patients on continuous ambulatory peritoneal dialysis. Perit Dial Int 1996; 16 (Suppl 1): S492- S494.

4. Ma KW, Greene EL, Raij L. Cardiovascular risk factors in chronic renal failure and hemodialysis populations. Am J Kidney Dis 1992; 19: 505-513, doi: 10.1016/S0272-6386 (12)80827-4.

5. Papagianni A, Kalovoulos M, Kirmizis D, Vainas A, Belechri AM, Alexopoulos E, et al. Carotid atherosclerosis is associated with inflammation and endothelial cell adhesion molecules in chronic haemodialysis patients. Nephrol Dial Transplant 2003; 18: 113-119, doi: 10.1093/ndt/18.1.113.

6. Shroff R. Monitoring cardiovascular risk factors in children on dialysis. Perit Dial Int 2009; 29 (Suppl 2): 3-S175.

7. Guerin AP, Pannier B, Marchais SJ, London GM. Cardiovascular disease in the dialysis population: prognostic significance of arterial disorders. Curr Opin Nephrol Hypertens 2006; 15: 105-110, doi: 10.1097/01.mnh.0000203186. 11772.21 .

8. Yao Q, Axelsson J, Stenvinkel P, Lindholm B. Chronic systemic inflammation in dialysis patients: an update on causes and consequences. ASAIO J 2004; 50: lii-Ivii, doi: 10.1097/01.MAT.0000147958.87989.EB.

9. Filiopoulos V, Hadjiyannakos D, Takouli L, Metaxaki P, Sideris $\checkmark$, Vlassopoulos D. Inflammation and oxidative stress in endstage renal disease patients treated with hemodialysis or peritoneal dialysis. Int J Artif Organs 2009; 32: 872-882.

10. Guo $\mathrm{CH}$, Wang $\mathrm{CL}$, Chen $\mathrm{PC}$, Yang TC. Linkage of some trace elements, peripheral blood lymphocytes, inflammation, and oxidative stress in patients undergoing either hemodialysis or peritoneal dialysis. Perit Dial Int 2011; 31: 583-591, doi: $10.3747 /$ pdi.2009.00225.

11. Huang N, Hauck C, Yum MY, Rizshsky L, Widrlechner MP, McCoy JA, et al. Rosmarinic acid in Prunella vulgaris ethanol extract inhibits lipopolysaccharide-induced prostaglandin E2 and nitric oxide in RAW 264.7 mouse macrophages. J Agric Food Chem 2009; 57: 10579-10589, doi: 10.1021/jf9023728

12. Jiang WL, Chen XG, Qu GW, Yue XD, Zhu HB, Tian JW, et al. Rosmarinic acid protects against experimental sepsis by inhibiting proinflammatory factor release and ameliorating hemodynamics. Shock 2009; 32: 608-613, doi: 10.1097/ SHK.0b013e3181a48e86.

13. Zdarilova A, Svobodova A, Simanek V, Ulrichova J. Prunella vulgaris extract and rosmarinic acid suppress lipopolysaccharide-induced alteration in human gingival fibroblasts. Toxicol In vitro 2009; 23: 386-392, doi: 10.1016/j.tiv.2008. 12.021.
14. Sanbongi C, Takano H, Osakabe N, Sasa N, Natsume M, Yanagisawa $\mathrm{R}$, et al. Rosmarinic acid in perilla extract inhibits allergic inflammation induced by mite allergen, in a mouse model. Clin Exp Allergy 2004; 34: 971-977, doi: 10.1111/j.1365-2222.2004.01979.x.

15. Ticli FK, Hage LI, Cambraia RS, Pereira PS, Magro AJ, Fontes MR, et al. Rosmarinic acid, a new snake venom phospholipase A2 inhibitor from Cordia verbenacea (Boraginaceae): antiserum action potentiation and molecular interaction. Toxicon 2005; 46: 318-327, doi: 10.1016/j.toxicon. 2005.04.023.

16. Englberger W, Hadding U, Etschenberg E, Graf E, Leyck S, Winkelmann J, et al. Rosmarinic acid: a new inhibitor of complement C3-convertase with anti-inflammatory activity. Int J Immunopharmacol 1988; 10: 729-737, doi: 10.1016/ 0192-0561(88)90026-4.

17. Osakabe N, Yasuda A, Natsume M, Sanbongi C, Kato Y, Osawa $\mathrm{T}$, et al. Rosmarinic acid, a major polyphenolic component of Perilla frutescens, reduces lipopolysaccharide (LPS)-induced liver injury in D-galactosamine (D-GaIN)sensitized mice. Free Radic Biol Med 2002; 33: 798-806, doi: 10.1016/S0891-5849(02)00970-X.

18. Pugin J, Ulevitch RJ, Tobias PS. Activation of endothelial cells by endotoxin: direct versus indirect pathways and the role of CD14. Prog Clin Biol Res 1995; 392: 369-373.

19. Lo HP, Ackland-Berglund CE, Pritchard KA Jr, Guice KS, Oldham KT. Attenuated expression of inducible nitric oxide synthase in lung microvascular endothelial cells is associated with an increase in ICAM-1 expression. $J$ Pediatr Sur. 2001; 36: 1136-1142, doi: 10.1053/jpsu.2001.25731.

20. Zimmermann J, Herrlinger S, Pruy A, Metzger T, Wanner C. Inflammation enhances cardiovascular risk and mortality in hemodialysis patients. Kidney Int 1999; 55: 648-658, doi: 10.1046/j.1523-1755.1999.00273.x.

21. Zoccali C, Benedetto FA, Mallamaci F, Tripepi G, Fermo I, Foca A, et al. Inflammation is associated with carotid atherosclerosis in dialysis patients. Creed Investigators. Cardiovascular risk extended evaluation in dialysis patients. J Hypertens 2000; 18: 1207-213, doi: 10.1097/00004872200018090-00006.

22. Wang W, Deng M, Liu X, Ai W, Tang Q, Hu J. TLR4 activation induces nontolerant inflammatory response in endothelial cells. Inflammation 2011; 34: 509-518, doi: 10.1007/s10753010-9258-4.

23. Suzuki J, Bayna E, Li HL, Molle ED, Lew WY. Lipopolysaccharide activates calcineurin in ventricular myocytes. J Am Coll Cardiol 2007; 49: 491-499, doi: 10.1016/j.jacc. 2006.10.043.

24. Weglarz L, Dzierzewicz Z, Skop B, Orchel A, Parfiniewicz B, Wisniowska $B$, et al. Desulfovibrio desulfuricans lipopolysaccharides induce endothelial cell IL-6 and IL-8 secretion and E-selectin and VCAM-1 expression. Cell Mol Biol Lett 2003; 8: 991-1003.

25. Buesing $\mathrm{KL}$, Densmore JC, Kaul S, Pritchard KA Jr, Jarzembowski JA, Gourlay DM, et al. Endothelial microparticles induce inflammation in acute lung injury. $J$ Surg Res 2011; 166: 32-39, doi: 10.1016/j.jss.2010.05.036. 
26. Desai TR, Leeper NJ, Hynes KL, Gewertz BL. Interleukin-6 causes endothelial barrier dysfunction via the protein kinase C pathway. J Surg Res 2002; 104: 118-123, doi: 10.1006/ jsre.2002.6415.

27. Lonnemann G. Chronic inflammation in hemodialysis: the role of contaminated dialysate. Blood Purif 2000; 18: 214-223, doi: $10.1159 / 000014420$.

28. Raij L, Shapiro FL, Michael AF. Endotoxemia in febrile reactions during hemodialysis. Kidney Int 1973; 4: 57-60, doi: 10.1038/ki.1973.79.

29. Nishida M, Ando M, Iwamoto Y, Tsuchiya K, Nitta K. New insight into atherosclerosis in hemodialysis patients: overexpression of scavenger receptor and macrophage colonystimulating factor genes. Nephron Extra 2016; 6: 22-30, doi: 10.1159/000448486.

30. El-Shehaby AM, El-Khatib MM, Marzouk S, Battah AA. Relationship of Bsml polymorphism of vitamin D receptor gene with left ventricular hypertrophy and atherosclerosis in hemodialysis patients. Scand J Clin Lab Invest 2013; 73: 75-81, doi: 10.3109/00365513.2012.743163.

31. Constantin-Teodosiu D, Greenhaff PL, Gardiner SM, Randall MD, March JE, Bennett T. Attenuation by creatine of myocar- dial metabolic stress in Brattleboro rats caused by chronic inhibition of nitric oxide synthase. Br J Pharmacol 1995; 116: 3288-3292, doi: 10.1111/j.1476-5381.1995.tb15137.x.

32. Gardiner SM, Kemp PA, March JE, Bennett T. Cardiac and regional haemodynamics, inducible nitric oxide synthase (NOS) activity, and the effects of NOS inhibitors in conscious, endotoxaemic rats. $\mathrm{Br} J$ Pharmacol 1995; 116: 2005-2016, doi: 10.1111/j.1476-5381.1995.tb16405.x.

33. Heitzer T, Schlinzig T, Krohn K, Meinertz T, Munzel T. Endothelial dysfunction, oxidative stress, and risk of cardiovascular events in patients with coronary artery disease. Circulation 2001; 104: 2673-2678, doi: 10.1161/hc4601.099485.

34. Liu HT, Huang P, Ma P, Liu QS, Yu C, Du YG. Chitosan oligosaccharides suppress LPS-induced IL-8 expression in human umbilical vein endothelial cells through blockade of p38 and Akt protein kinases. Acta Pharmacol Sin 2011; 32 : 478-486, doi: 10.1038/aps.2011.10.

35. Ponce C, Torres M, Galleguillos C, Sovino H, Boric MA, Fuentes $A$, et al. Nuclear factor kappaB pathway and interleukin-6 are affected in eutopic endometrium of women with endometriosis. Reproduction 2009; 137: 727-737, doi: 10.1530/REP-08-0407. 